\title{
Substitution of Sweet Potato (Ipomoea Batatas) and Soybean (Glycine Max.) Flour with Durum Wheat (Triticum Durum) Flour Effect on Physicochemical and Sensory Characteristics of Cookies
}

\author{
Tadewos Hadero Gezahegn Nigusse \\ Food Science and Postharvest Technology, College of Agriculture, Hawassa University, Ethiopia \\ Tadewos Hadero* \\ School of Nutrition, Food Science and Technology, College of Agriculture Hawassa University \\ P. O. Box: 5, Hawassa, Ethiopia
}

\begin{abstract}
Cookie production is currently limited to wheat and few cereal grains in many countries. This study was initiated with the objectives of investigating the possibility of producing cookies from blends of durum wheat, sweet potato and fermented soybean flours at the ratio of 100:0:0, 75:25:0, 75:0:25, 75:22.5:2.5, 75:2.5:22.5, 75:20:5, 75:5:20, 75:17.5:7.5, 75:7.5:17.5, respectively. The cookies were evaluated for physical properties such as diameter, thickness, and spread ratio; proximate compositions (moisture content, total ash, crude fat and crude protein); and sensory attributes like color, taste, crispness, texture, appearance and overall acceptability. Physical characteristics; the ratio of sweet potato and soybean flour increased in cookies preparation with wheat flour increased the diameter, thickness and spreading factor of cookies to some extent. There were valuable effect on proximate composition of the product (sweet potato and soybean ratio increase in cookies formulation made irregular increase and decrease, respectively in the product moisture content. The fat content of cookies was decreased and irregularly increased with increased ratio of both sweet potato and soybean, respectively. Both sweet potato and soybean ratio increment in the product, resulted in the irregular increase of total ash. Protein content of cookies was decreased for the increased ratio of sweet potato and increased for the increased ration of soybean. Sensory acceptability evaluation of the product based on color, taste, crispness, texture, appearance and overall acceptability was preferred by the panelists without any difference.
\end{abstract}

Keywords: Cookies, physical properties, proximate composition, sensory characteristics.

DOI: $10.7176 / F S Q M / 83-02$

\section{Introduction}

\subsection{Background an justification}

Wheat (Triticum aestivum L.) is a major staple crop to billions of people around the world and is used in a wide variety of food products such as bread, breakfast cereal, flatbreads, tortillas, cookies, pie crusts, soup thickeners, noodles and gravies (Lev-Yadun et al., 2000). Wheat meal used for human consumption provides $20 \%$ of all the energy consumed by the human population. In addition to being a fundamental source of calories and nutrients, wheat is an economically important crop around the world.

Sweet potato (Ipomoea batatas L.) is one of locally available food crops used to consume in many parts of the world in East Africa. It is most versatile for snack food, but it is used as staple food or as a substitute in many countries for different types of foods (Zuraida, 2003). It is a low input crop, wide production geography, adaptability to marginal condition, short production cycle, high nutritional value and sensory versatility in terms of flesh colors, taste and texture. It ranks the seventh most important food crop in the world and fourth in tropical countries (FAO, 2008). Sweet potatoes comprise $\beta$-carotene, anthocyanins, total phenolics, dietary fiber, ascorbic acid, folic acid and minerals (Chassy et al., 2008).

Soybean (Glycine max.) is rich in dietary proteins and low-cost sources nutrients for a large part of the world's population (Egounlety and Aworh, 2003). These grain legumes contribute significantly towards protein (about 35-40\%), mineral and B-complex vitamin needs of people in developing countries (Dhingra and Jood, 2002), and play an important role in the traditional diets of many regions throughout the world. It is a very rich source of vegetable protein for all including growing children (Dandago and I.G.W.E., 2006); and it has been identified as a suitable protein rich crop that could improve the nutritional and economic status of the general population in developing countries (Babajide et al., 2003). The reasonable price and steady supply are also favorable factors in soybeans emerging as an important source of protein in nutrition. Soybean production in Ethiopia is very crucial to overcome malnutrition and it is cheap substitute for expensive animal protein.

Cookies are flat, dry which is produced from a mixture of flour and water which may contain fat, sugar and other ingredients mixed together into dough. Research into the use of tropical crops has shown that biscuits and other pastries such as meat-pie, cookies, cake, etc. could be made from flours of locally available crops such as 
sweet potato, cassava, rice, millet, sorghum, etc. It represents the largest category of snack item among baked food products throughout the world (Pratima and Yadave, 2000). It provides an excellent means of improving the nutritional quantity of foods through incorporation of less expensive high quality protein, minerals, vitamins and has been employed in food product enrichment. Cookies hold an important position in snack foods due to variety in taste, crispiness and digestibility. Most of bakery products are used as a means for incorporating different nutritionally rich ingredients for their diversification (Sudha et al., 2007); such enrichment may be attained through the incorporation of protein rich non-wheat flours (Sharma and Chauhan, 2002). Protein-energy malnutrition, in children associated with poor nutritional knowledge resulting in early weaning, delayed introduction of complimentary foods, low protein diet and sever or frequent infection (Ramakrishna ad Jhanesi, 2006). Sub-Saharan African bears the brunt of protein-energy malnutrition in the world (Muller and Krawinkel, 2011). In Ethiopia the most important nutritional problem in foods consumed by the children in many parts are protein-energy malnutrition, micronutrient and macronutrients deficiency (Bukusuba et al., 2010).

The increasing phenomenon of urbanization, coupled with the growing number of working mothers, have contributed greatly to the popularity and increased consumption of snack foods such as cookies and biscuits. However, wheat flour, which is the flour of choice for producing cookies and other baked food products, is either unavailable or uneconomical in many regions of the world. Therefore, to produce baked goods, regions with limited supplies of wheat flour must rely on imports or exclude wheat products from the diet. The production of cereal-based baked products like cookies at an affordable cost therefore requires the development of an adequate substitute for wheat. The substitute should be one that is readily available, cheap and able to replace wheat flour in terms of functionality. Flours produced from only either cereals, legumes or tubers were have a nutritional value inferior to those produced from a combination of cereals, legumes or tubers. For instance, composite flours produced from cereals and legumes have the advantage of improving the overall nutrition while composite flours produced from legumes and tubers was have high protein content and high calorific value. In selecting the components to be used in composite flour blends, the materials should preferably be readily available, culturally acceptable and provide increased nutritional potentials.

Therefore, the purpose of this study was to investigate the product of sweet potato, fermented soy bean and durum wheat flour cookies nutritional status, physicochemical properties and organoleptic acceptability which benefits in combating protein nutrient deficiency.

\subsection{Objectives}

\subsubsection{General objective}

To evaluate the effects of blending ratio of sweet potato and soybean flour on physicochemical and sensory characteristics of cookies produced from durum wheat flour.

\subsubsection{Specific objectives}

1. To prepare cookies from sweet potato, soybean and durum wheat flour.

2. To analyze proximate composition of cookies produced from durum wheat, sweet potato and soybean composite flours.

3. To examine the physical properties of cookies produced from durum wheat, sweet potato and soybean composite flours.

4. To evaluate sensory quality of cookies made from blending of durum wheat, sweet potato and soybean composite flours.

\section{Materials and Methods}

\subsection{Raw material collection}

Three kinds of raw materials, i.e., wheat, soybean, and sweet potato were obtained from Hawassa Agricultural Research Center (HARC), Ethiopia, while ingredients such as milk, sugar, egg, oil, salt, water, and baking powder were obtained from Hawassa local market.

\subsection{Experimental design}

The experiment was done by two way analysis of variance (ANOVA) (factorial), complete randomized design (CRD) was used to evaluate physicochemical properties, and complete randomized block design (CRBD) was applied for sensory evaluation. Data was collected in replicate and the average was taken for data analysis. 
Table 1. Percentage of different treatment used to prepare cookies.

\begin{tabular}{llll}
\hline Treatment & Durum wheat flour (\%) & Sweet potato flour (\%) & Soybean flour (\%) \\
\hline Control & 100 & 0 & 0 \\
T1 & 75 & 25 & 0 \\
T2 & 75 & 0 & 25 \\
T3 & 22.5 & 2.5 \\
T4 & 75 & 2.5 & 22.5 \\
T5 & 75 & 20 & 5 \\
T6 & 55 & 5 & 20 \\
T7 & 75 & 17.5 & 7.5 \\
T8 & 75 & 7.5 & 17.5 \\
\hline
\end{tabular}

Source: Sukhcharn et al. (2008)

\subsection{Composite flour formation}

Durum wheat, sweet potato and soybean flour were mixed at ratio of 100:0:0, 75:25:0, 75:0:25, 75:20:5, 75:5:20, 75:15:10, 75:10:15, 75:17.5:7.5, 75:7.5:17.5, respectively as of Sukhcharn et al. (2008), in a Kenwood blender. The blends were kept in airtight containers at room temperature for cookies preparation.

\subsection{Cookies preparation procedures}

Cookies were prepared according to the method of AACC (2000) with some modification in the recipe. Flour $(100 \mathrm{~g})$ from each sample of different flour blend, corn starch $10 \mathrm{~g}$, sugar $7.5 \mathrm{~g}$, baking powder $12 \mathrm{~g}$, four egg $(120 \mathrm{~g})$, oil $0.5 \mathrm{ml}$, salt $1 \mathrm{~g}$ and the $75 \mathrm{ml}$ of water were added. The dry ingredients (composite flour, sugar, salt and baking powder) were mixed until uniform mixtures of the ingredients obtained. Egg was then added and the mixtures were needed.

The butter was rolled and cut with cookie cutter (knife in this case). The cookies were placed in baking trays, leaving $25 \mathrm{~mm}$ space in between and baked at $180^{\circ} \mathrm{C}$ for 10 minutes in the baking oven. Following baking, the cookies were cooled on a wire racks at $27^{\circ} \mathrm{C}$ for 30 minutes and packed in polyethylene bags and stored in cool and dry area. The ingredient used was shown in Table 6 . The dry ingredients were weighed using an analytical balance and thoroughly mixed.

\subsection{Physicochemical properties}

\subsubsection{Physical Property determination}

The cookies were selected randomly for physical properties (diameter, thickness, and spread ratio) evaluation and examined according to Zoulias et al. (2000). The weight, height and diameter of the baked cookies were determined by weighing on a weighing balance (Mettler PE160 Balance, Switzerland) and measuring with a calibrated ruler, respectively on duplicate samples of cookies.

\subsubsection{Chemical composition determination}

The moisture content, crude fat, crude protein and total ash were determined according to the AOAC (2005) methods on duplicate samples of the cookies.

\subsection{Sensory evaluation}

Sensory characteristics (such as color, taste, crispness, texture, appearance and overall acceptability) of cookies sample were evaluated in duplicate by 20 trained panelist using 7 point hedonic (Moreira, 2008).

\subsection{Data analysis}

The data obtained was subjected to analysis of variance (ANOVA), followed by the General Linear Model of the Statistical Analysis System (SAS for windows; SAS 9. 1 software version, Institute, Inc. Cary, NC, USA) and mean comparisons were made by Duncan's Multiple Range Test at significance level of $\mathrm{p} \leq 5 \%$.

\section{Results and Discussions \\ 3.1 Physical properties}

\subsubsection{Diameter}

The diameter of cookies is presented in Table 2 . There was a significant $(p<0.05)$ difference on the diameter of cookies developed by the blends of durum wheat, sweet potato and soybean. The increase in sweet potato flour ratio made the increase in the diameter of cookies. This might be due to high protein, specifically gluten protein content in wheat brought the elasticity. 
Table 2. Physical property evaluation of cookies.

\begin{tabular}{llll}
\hline Blends & Diameter(cm) & Thickness(cm) & Spread ratio \\
\hline C (100W:0soy:0sp) & $4.04 \pm 0.01^{\mathrm{d}}$ & $0.86 \pm 0.03^{\mathrm{a}}$ & $0.19 \pm 0.01^{\mathrm{a}}$ \\
T1 (75W:25soy:0sp) & $4.01 \pm 0.01^{\mathrm{de}}$ & $0.79 \pm 0.02^{\mathrm{b}}$ & $0.17 \pm 0.01^{\mathrm{b}}$ \\
T2 (75W:0soy:25sp) & $4.19 \pm 0.02^{a}$ & $0.47 \pm 0.04^{f}$ & $0.11 \pm 0.01^{e}$ \\
T3 (75W:2.5soy:22.5sp) & $4.10 \pm 0.01^{c}$ & $0.54 \pm 0.01^{e}$ & $0.13 \pm 0.00^{d}$ \\
T4 (75W:22.5soy:2.5sp) & $4.12 \pm 0.01^{b c}$ & $0.61 \pm 0.01^{d}$ & $0.14 \pm 0.00^{c d}$ \\
T5 (75W:5soy:20sp) & $4.02 \pm 0.01^{d e}$ & $0.56 \pm 0.02^{d e}$ & $0.14 \pm 0.01^{c d}$ \\
T6 (75W:20soy:5sp) & $4.14 \pm 0.01^{b}$ & $0.72 \pm 0.01^{c}$ & $0.15 \pm 0.00^{c}$ \\
T7 (75W:17.5soy:7.5sp) & $4.02 \pm 0.04^{d e}$ & $0.60 \pm 0.10^{d}$ & $0.12 \pm 0.02^{d e}$ \\
T8 (75W:7.5soy:17.5sp) & $3.10 \pm 0.02^{e}$ & $0.60 \pm 0.02^{d}$ & $0.14 \pm 0.01$ \\
\hline LSD & 0.0416 & 0.064 & 0.0173 \\
\hline
\end{tabular}

Mean \pm Standard deviation values within columns bearing with the same superscripts are not significantly different at $\mathrm{p}<0.05$.

This is supported by the finding of Pareyt and Delcour (2008) and Shazia et al. (2012), reported that the diameter of cookies developed from wheat and OFSP blend flour was increased. So that the diameter was reduced due to the lower elasticity nature in sweet potato flour. When the proportion of soya bean increased in the blended cookies, the diameter of cookies' was increased irregularly, this could be due to the lower elasticity nature of the soya bean protein (Pragya et al., 2016 and Abayomi et al., 2013).

\subsubsection{Thickness}

As shown on Table 2, there was a significant difference on the thickness of C, T1, T2, T3, T5, and T6 cookies developed by the blends of durum wheat, sweet potato and soybean at $(\mathrm{p}<0.05)$. The thickness of cookies decreased when more sweet potato flour was added to wheat during the cookies development. This is agreed with the finding of Shazia et al. (2012) and Sukhcharn et al. (2008) were reported that thickness of cookies developed from sweet potato supplemented with wheat flour was reduced with addition of more sweet potato flour. This might be due to the heat applied and water holding capacity of potato flour (Pragya et al., 2016). The ratio of soybean increased regularly but the thickness of cookies was increased irregularly. This might be due to the lower elasticity nature of the soya bean protein (Pragya et al., 2016 and Abayomi et al., 2013).

\subsubsection{Spread Ratio}

The spread ratio of cookies presented in Table 2 indicated that the increase in sweet potato flour supplementation made the decrease in spread ratio of cookies. The present study finding was similar to the findings of Sharif et al. (2009), who reported that spread factor of sweet potato flour supplemented wheat cookies decreased with the increasing of sweet potato flour. This might be due to water absorption capacity difference of sweet potato and wheat flour. Sukhcharn et al. (2008) reported that spread factor of cookies developed from wheat was higher than sweet potato blends. The spread factor was greater for cookies made from wheat flour and decreased significantly with increasing of sweet potato proportion (Jemziyal and Mahendran, 2017). The finding was in line with the present study due to decreasing of spread factor by addition of more sweet potatoes in wheat during cookies development. When the proportion of soya bean increased in the blended cookies, the spread ratio of cookies' were irregularly increased, this might due to the fact that the lower elasticity nature of the soya bean protein (Pragya et al., 2016).

\subsection{Proximate analysis}

\subsubsection{Moisture content}

As shown on Table 3, there was a significant $(\mathrm{p}<0.05)$ difference in the moisture content of T2, T3, and T4 of the developed cookies, while there was no difference on $\mathrm{C}$ and T6, T1 and T7, and T5 and T8. With an increase in the sweet potato flour in the cookies, there was an irregular increase in the moisture content. This could be probably due to high water binding capacity of the starch in the sweet potato flour, which is in line with the finding of (Njintang et al., 2007). Moreover, the study reported by Gebremedhin et al. (2013), and Omer et al. (2014) on sweet potato and wheat blended bread, and on sorghum and sweet potato blended flat-bread, respectively were indicated that the increase in substitution level of sweet potato were associated with increased level of moisture content. Increased proportion of soybean resulted in irregular decrease of moisture content of cookies, this was agreed with the finding of Tharise et al. (2014), composite flour from cassava, rice, potato, soybean and xanthan gum the increment in soybean showed irregularity in moisture content.

\subsubsection{Ash content}

The blending proportion of soybean and sweet potato were found to have significant $(\mathrm{p}<0.05)$ effect on the ash 
content of the cookies (Table 3). It was observed that the proportion of sweet potato flour and soybean flour increase in the blend, resulted in irregular increase in the ash content of the product. This result is in agreement with the result reported by Vasantharuba et al. (2012) about sweet potato and wheat blended bread, and also incorporation of sweet potato flour and soybean flour in making cookies enhanced the mineral content, as ash is an indicative of the amount of minerals content in any food sample (Laoye et al., 2007).

Table 3. Proximate composition of cookies

\begin{tabular}{lllll}
\hline Blends & MC & Ash & Fat & protein \\
\hline C (100W:0soy:0sp) & $7.69 \pm 0.55^{\mathrm{f}}$ & $2.25 \pm 0.00^{d}$ & $15.25 \pm 0.35^{c}$ & $13.25 \pm 0.35^{\mathrm{e}}$ \\
T1 (75W:25soy:0sp) & $6.64 \pm 0.51^{e}$ & $2.95 \pm 0.35^{b c}$ & $17.75 \pm 0.35^{a}$ & $21.75 \pm 0.35^{a}$ \\
T2 (75W:0soy:25sp) & $12.95 \pm 0.13^{a}$ & $3.75 \pm 0.35^{b c}$ & $12.75 \pm 0.35^{e}$ & $12.75 \pm 0.35^{\mathrm{g}}$ \\
T3 (75W:2.5soy:22.5sp) & $11.82 \pm 0.54^{b}$ & $3.45 \pm 0.00^{b}$ & $12.75 \pm 0.35^{e}$ & $16.75 \pm 0.35^{\mathrm{f}}$ \\
T4 (75W:22.5soy:2.5sp) & $10.82 \pm 0.34^{\mathrm{c}}$ & $3.00 \pm 0.35^{\mathrm{c}}$ & $17.25 \pm 0.35^{a}$ & $20.25 \pm 0.35^{\mathrm{b}}$ \\
T5 (75W:5soy:20sp) & $9.24 \pm 0.17^{d}$ & $3.55 \pm 0.35^{c d}$ & $13.25 \pm 0.35^{e}$ & $17.25 \pm 0.35^{e}$ \\
T6 (75W:20soy:5sp) & $7.03 \pm 0.69^{\mathrm{f}}$ & $3.95 \pm 0.35^{a}$ & $16.25 \pm 0.35^{b}$ & $19.25 \pm 0.35^{\mathrm{c}}$ \\
T7 (75W:17.5soy:7.5sp) & $8.24 \pm 0.17^{\mathrm{e}}$ & $2.75 \pm 0.35^{b c}$ & $14.25 \pm 0.35^{d}$ & $18.25 \pm 0.35^{d}$ \\
T8 (75W:7.5soy:17.5sp) & $10.39 \pm 0.81^{\mathrm{d}}$ & $2.75 \pm 0.35^{b c}$ & $15.75 \pm 0.35^{b c}$ & $18.75 \pm 0.35^{\mathrm{d}}$ \\
\hline LSD & 1.1045 & 0.4554 & 0.7998 & 1.1045 \\
\hline
\end{tabular}

Mean \pm Standard deviation values within columns bearing with the same superscripts are not significantly different at $\mathrm{p}<0.05$.

$$
\text { 3.2.3 Fat }
$$

The fat content of cookies was significantly affected at $(\mathrm{p}<0.05)$ by blend proportions of wheat, sweet potato and soybean (Table 3). As the amounts of sweet potato flour in the formulation increased, the amount of fat in the cookies decreased. This might be due to the presence of high fat in wheat than in sweet potato flour as the finding reported by Ifie (2011), who found the same trend on madiga (local bread in Nigeria) produced from composite flour of sweet potato and wheat blend. However, the decrease in the fat contents of the composite cookies observed in this study could be due to the heat imposed, duration of heating and the $\mathrm{pH}$ that leads to the destruction of nutrients Sharif et al. (2009). There was an irregular increase in fat content due to the increase in soybean flour proportion. This indicates that supplementing sweet potato flour with soybean flour could be greatly improved the protein quality of cookies (Pragya et al., 2016). This could be due to the significant quantity of protein in the soy bean flour.

\subsubsection{Protein}

As Table 3 presented, there was a significant $(\mathrm{p}<0.05)$ difference in the protein content of the developed cookies. With an increased amount of soybean in the cookies, there was an increase in the protein content in soybean incorporated cookies. This indicates that supplementing wheat and soy bean flour would greatly improve the protein nutritional quality of cookies produced Pragya et al. (2016). On the other hand, as the amounts of sweet potato flour in the formulation increased, resulted in decreased amount of protein in the cookies, which is inversely proportional. This could be due to low protein content of sweet potato. Similar report was made by Okorie and Onyeneke (2012), for cookies from sweet potato and wheat.

\subsection{Sensory evaluation}

The sensory evaluation of the cookies revealed that there were no differences (Table 4) among the entire samples; this implies that control sample and treated samples were equally preferred by the panelists. This was similar to the finding reported in West Kenya on OFSP and sweet potato incorporated food product (Rono et al., 2006), which was accepted in producers and consumers side. Vasantharuba et al. (2012) also reported that a substitution of $30 \%$ of wheat flour by sweet potato flour was feasible and acceptable for baked products. Consumer tests in a market in Mozambique showed a strong preference for golden bread made with boiled and mashed sweet potato $38 \%$ of weight of wheat flour (Graham et al., 2009). This result was also in agreement with Sukhcharn et al. (2008); this states that the substitution level of sweet potato flour for cookies up to $40 \%$ was acceptable. Greene et al. (2004) reported that sweet potato flour can be used as substitute of wheat flour in amount of $25-50 \%$, specifically in baked products without the change in the acceptability on the sensory attributes (Vasantharuba et al., 2012). 
Table 4. Sensory evaluation of cookies

\begin{tabular}{|c|c|c|c|c|c|c|}
\hline Blends & Color & Taste & Crispness & Texture & Appearance & Over all acceptability \\
\hline C (100W:0soy:0sp) & $6.20 \pm 1.42^{a}$ & $6.20 \pm 1.40^{a}$ & $6.47 \pm 1.50^{a}$ & $6.63 \pm 1.61^{a}$ & $6.23 \pm 1.41^{a}$ & $6.83 \pm 1.42^{a}$ \\
\hline T1 (75W:25soy:0sp) & $6.88 \pm 1.38^{a}$ & $6.66 \pm 1.31^{a}$ & $6.93 \pm 1.62^{a}$ & $6.47 \pm 1.25^{a}$ & $6.77 \pm 1.55^{a}$ & $6.70 \pm 1.21^{a}$ \\
\hline T2 (75W:0soy:25sp) & $6.03 \pm 1.62^{a}$ & $6.76 \pm 1.33^{a}$ & $6.94 \pm 1.16^{a}$ & $6.30 \pm 1.53^{a}$ & $6.23 \pm 1.54^{a}$ & $6.70 \pm 1.49^{a}$ \\
\hline T3 (75W:2.5soy:22.5sp) & $6.87 \pm 1.35^{a}$ & $6.97 \pm 1.50^{a}$ & $6.77 \pm 1.77^{a}$ & $6.80 \pm 1.75^{a}$ & $6.50 \pm 1.48^{a}$ & $6.93 \pm 1.60^{a}$ \\
\hline T4 (75W:22.5soy:2.5sp) & $6.13 \pm 1.25^{a}$ & $6.93 \pm 0.97^{a}$ & $6.47 \pm 1.26^{a}$ & $6.93 \pm 1.17^{a}$ & $6.17 \pm 1.29^{a}$ & $6.33 \pm 1.10^{a}$ \\
\hline T5 (75W:5soy:20sp) & $6.67 \pm 1.12^{a}$ & $6.97 \pm 1.25^{a}$ & $6.80 \pm 1.45^{a}$ & $6.67 \pm 1.21^{a}$ & $6.83 \pm 1.64^{a}$ & $6.10 \pm 1.77^{a}$ \\
\hline T6 (75W:20soy:5sp) & $6.64 \pm 0.84^{a}$ & $6.37 \pm 0.93^{a}$ & $6.71 \pm 1.07^{a}$ & $6.54 \pm 0.98^{a}$ & $6.47 \pm 1.01^{a}$ & $6.87 \pm 0.90^{a}$ \\
\hline T7 (75W:17.5soy:7.5sp) & $6.70 \pm 1.18^{a}$ & $6.90 \pm 1.24^{a}$ & $6.80 \pm 1.13^{a}$ & $6.87 \pm 1.22^{a}$ & $6.70 \pm 1.37^{a}$ & $6.13 \pm 1.38^{a}$ \\
\hline T8 (75W:7.5soy:17.5sp) & $6.30 \pm 1.62^{a}$ & $6.03 \pm 1.45^{a}$ & $6.90 \pm 1.58^{a}$ & $6.850 \pm 1.36^{a}$ & $6.87 \pm 1.85^{a}$ & $6.13 \pm 1.72^{a}$ \\
\hline LSD & 0.2265 & 0.2488 & 0.2177 & 0.293 & 0.2482 & 0.222 \\
\hline
\end{tabular}

Mean \pm Standard deviation values within columns bearing with the same superscripts are not significantly different at $\mathrm{p}<0.05$.

\section{Conclusion and Recommendation \\ 4.1 Conclusion}

Blends of sweet potato and soybean flour with wheat flour have significant effect on the physical properties of the cookies. Cookies from wheat, soybean and sweet potato flour blends had improved proximate composition compared to cookies from wheat to some extent. This study has shown that cookies containing $20 \%, 5 \%, 7.5 \%$ and $5 \%$ soybean flour and 5\%,20\%, 17.5\% and 20\% sweet potato flour have great potentials and compare favorably with $100 \%$ wheat in moisture, ash, fat and protein content. Thus their use would go a long way in reducing dependency on importing wheat for wheat flour preparations. Sweet potato and soybean flour mixed with wheat flour cookies have equally accepted in physical and organoleptic characteristics as compared to $100 \%$ wheat flour cookies.

\subsection{Recommendations}

The outcome of the present research can be used as valuable information source for the development of high fiber low gluten sweet crunchy cookies. The results obtained could be very valuable in decision making for industries that want to take nutritional advantage of sweet potato flour as alternative or supplement to cereal flours. However, more research is recommended:

- as if the shelf life of the cookies is determined to evaluate the keeping quality of the product.

- as if the functional quality of the composite flour is determined.

\section{References}

AACC (American Association of Cereal Chemists). (2000). Approved methods of the American Association of Cereal Chemists. $\left(10^{\text {th }}\right.$ ed.). Inc., St. Paul, MN: USA.

Abayomi, H. T., Oresanya, T. O., Opeifa, A. O., and Rasheed, T. R. (2013). Quality evaluation of cookies produced from blends of sweet potato and fermented soybean flour, World Academy of Science, Engineering and Technology. International Journal of Nutrition and Food Engineering, Vol: 7, No: 7.

AOAC (Association of Official Analytical Chemists International). (2005). Official Methods of Analysis of AOAC International. (18 ${ }^{\text {th }}$ ed.). Washington DC: USA. 211-6.

Babajide, J. M., Idowu, M. A., and Lasekan, O. (2003). Effect of soy and wheat variation on the functional and sensory properties of cassava-soy wheat noodles. Nigerian Food Journal, Volume, 21, 23-28.

Bukusuba, J. f., Isabirye, F., and Nampala P. (2010). Effect of processing techniques on energy density and viscosity of cooking banana: Implication for weaning food in Uganda. International Food Science Technology, 43, 1424-1429.

Chassy, B. M., Egnin, Y., Gao, K., Glenn, G.A., Kleter, P., Nestel, M., Newell- McLoughlin, Phipp, R. H., and Shillito, R. (2008). Nutritionally improved sweet potato, in Nutritional and safety assessments of foods and feeds nutritionally improved through biotechnology: Case studies (prepared by a task force of the ILSI International food biotechnology committee). Comprehensive Reviews in Food Science and Food Safety, 7(1), 81-97.

Dandago, M.A., and I.G.W.E. (2006). Production and sensory evaluation of soya yoghurt. International Journal of Food and Agricultural Research, 3 (1), 36-39. 
Dhingra, and Jood, S. (2002). Physicochemical and nutritional properties of cereal-pulse blends for bread making. Nutritional Health, 16(3), 183-94.

Egounlety, and Aworh. (2003). Effect of soaking, dehulling, cooking and fermentation with Rhizopus oligosporus on the oligosaccharides, trypsin inhibitor, phytic acid and tannins of soybean (Glycine max Merr.), cowpea (Vignaunguiculata L. Walp) and ground bean (Macrotylomageocarpa Harms). Journal of Food Engineering, 56, 249-254.

FAO (Food and Agriculture Organization). (2008). Production and area harvested statistics for sweet potato for 2007. [Online] Available: http://www.faostat.fao.org/site/567/default.aspx?PageID=567\#ancor (September 15, 2011).

Gebremedhin Kidan, Kebede Abegaz, Afework Mulugeta, and Pragya. (2013). Nutritional analysis of vitamin A enriched bread from orange flesh sweet potato and locally available wheat flours at Samre Woreda. Northern Ethiopia. Current Research in Nutrition and Food Science, Vol. 1(1), 49-57.

Graham Thiele, John Lynam, Berga Lemaga, and Jan Low. (2009). Sweet potato value chains in Challenge Theme Paper 4. C I P, social sciences working paper.

Greene, J., Bowell, L., and Benjamin, A. C. (2004). Macroscopic and sensory evaluation of sensory bread supplemented with sweet potato flour. Journal of food science, 69(4), 167-173.

Ifie Idolo. (2011). Sensory and nutritional quality of madiga produced from composite flour of wheat and sweet potato. Pakistan Journal of Nutrition, 10(11), 1004-1007.

Jemziyal, M.B.F., and Mahendran, T. (2017). Physical quality characters of cookies produced from composite blends of wheat and sweet potato flour. Ruhuna Journal of Science, Vol 8, 12- 23.

Laoye, O. A., Onilude, A. A., and Oladoye, C. O. (2007). Breadfruit flour in biscuit making: effects on product quality. African Journal of Food Science, 4, 20 - 23.

Lev-Yadun, S., Gopher, A., and Abbo, S. (2000). The cradle of agriculture science. 288, 1602-1603.

Moreira, M. (2008). Mild heat shock to extend the shelf life of minimally processed lettuce. Journal of Applied Horticulture, v.10, n. 2, 3-10.

Muller, O., and Krawinkel, M. (2011). Malnutrition and health in developing countries. CMAJ.2005. 173(3), 279-286. [Online] Available: http;//www.cmaj.ca/cgi/content /full/173/3/279 (November 21, 2012).

Njintang, Y.N., Mbofung, C.M., Balaam, F., Kitissou, P., and Scher, J. (2007). Effect of taro (Colocasia esculenta) flour addition on the functional and organoleptic properties of wheat flour and dough. Journal of the Science of Food and Agriculture, 88 (2), 273-279.

Okorie, S. U., and Onyeneke, E. N. (2012). Production and quality evaluation of baked cookies from blend of OFSP and wheat flour. Natural and Applied Sciences, volume 3 No. 2, (Department of Food Science and Technology, Imo State University, Owerri, NIGERIA,).

Omer Seid Adem, Pragya Singh and Getenesh Berhanu. (2014). Assessment of dietary consumption of vitamin A by preschool children in South Ethiopia: A cross sectional study. International Journal of Environmental Sciences, Vol.1 No.4, 2012, Pp.279-284.

Pareyt, B., and Delcour, J. A. (2008). The role of wheat flour constituents, sugar, and fat in low-moisture cereal based products, a review on sugar-snap cookies. Critical revolution of food science and nutrition, 48, 82439.

Pragya Johry, Samsher, Singh, G.R., Singh, B.R., Vaishali1, and Suresh Chandra. (2016). Development of cookies from potato flour and their quality evaluation. South Asian Journal of Food Technology Environment, 2(1), 309-312.

Pratima, A., and Yadave (2000). Effect of incorporation of liquid dairy by-product on chemical characteristic of soy fortified biscuits. Journal Food Science Technology, 37(2), 158-61.

Ramakrishna, V., and Jhanesi Rani, P. (2006). Anti-nutritional factors during germination in Indian bean (Dolichors lablabl) seed. World Journal of Dairy and Food Sciences, Pp6-11.

Rono, S.C., Wanyam, J. M., MoseL, O., Mutoko, J., Chesoro, C.M., Lusweti, E., Wanjekeche, and wachiye, B. (2006). Assessing house hold sweet potato incorporated diet among rural communities in North rift valley region of Kenya. Nairobi, Kenia. 234p.

Sharif, M. K., Butt, M. S., Anjum, F. M., and Nawaz, H. (2009). Preparation of fiber and mineral enriched defatted rice bran supplemented cookies. Pakistan Journal of Nutrition, 8(5), 571 - 577.

Sharma, and Chauhan, (2002). Effect of stabilized rice bran-fenugreek blends on the quality of breads and cookies. Journal Food Science and Nutrition, 39, 225-233.

Shazia, Saeed, Muhammad, Mushtaq, Ahmad, Humaira, Kausar, Saima, Parveen, Sharoon, Masih, and Abdusalam. (2012). Effect of sweet potato flour on quality of cookies. Journal of Agriculture Research, 50(4), $1-3$.

Sudha, Vetrimani, and Leelawathi. (2007). Influence of fiber from different cereals on the rheological characteristics of wheat flour dough and on biscuit quality. Food Chemistry, 100, 1364-1370.

Sukhcharn Singh., Riar, C. S., and Saxena, D.C. (2008). Effect of incorporating sweet potato flour to wheat flour 
on the quality characteristics of cookies. African. Journal of Food Science. V (2), 065-072.

Tharise, N., Julianti, E., and Nurminah, M. (2014). Evaluation of physicochemical and functional properties of composite flour from cassava, rice, potato, soybean and xanthan gum as alternative of wheat flour. International Food Research Journal, 21(4), 1641-1649.

Vasantharuba Seevaratnam, Banumathi, P., Premalatha, M.R., Sundaram, S.P., and Arumugam, T. (2012). Studies on the preparation of biscuits incorporated with potato flour. World Journal of Dairy and Food Sciences, 7 (1), 79-84.

Zoulias, P., Oreopoulou, Zoulias, E., I.Piknis, S., and Oreopoulou, V. (2000). Effect of sugar replacement by polyols and acesulfame-K on properties of low-fat cookies. Journal of the Science of Food and Agriculture, 80, 2049-2056.

Zuraida, N. (2003). Sweet potato as an alternative food supplement during rice storage. Journal of Lubang Pertanian, 22(4), 150-155. 